\title{
Deixis Analysis in the Business Article of the Jakarta Post
}

\author{
Herman $^{1}$, Hilman Pardede ${ }^{2}$ \\ ${ }^{1,2}$ English Education Department, Universitas HKBP Nommensen, Medan, Indonesia \\ e-mail: ${ }^{1}$ herman@uhn.ac.id, ${ }^{2}$ hilman.pardede@uhn.ac.id

\begin{tabular}{ccc}
\hline Diterima & Direvisi & Disetujui \\
$29-06-2020$ & $26-08-2020$ & $31-08-2020$ \\
\hline
\end{tabular}

\begin{abstract}
This research is conducted in order to find out the deixis in the business article of the Jakarta Post. Jakarta Post is as one of Indonesian newspaper, that use English as the media of communication, has lots of readers including national and international. Understanding the meaning of text in foreign language is a hard work to do for non-native readers. To achieve the sense of the text, deixis can be used to help the non-native readers. Theory divides the types of deixis into 5 types, (1) person deixis (2) place deixis (3) time deixis (4) discourse deixis (5) social deixis. Descriptive qualitative method was applied in this research. The source of data was the articles in the business of the Jakarta Post. The data were analyzed through a pragmatic theory stated by Levinson theory. After analyzing the data, the researchers found that: 1) all types of deixis found in the article of the Jakarta Post, 2) the dominant types of deixis found in the article of the Jakarta Post was person deixis.
\end{abstract}

Key Word: Deixis, pragmatics, sense, text

\begin{abstract}
Abstrak - Penelitian ini dilakukan untuk mengetahui deiksis dalam artikel bisnis di Harian Jakarta Post. Jakarta Post sebagai salah satu surat kabar Indonesia yang menggunakan bahasa Inggris sebagai media komunikasinya, memiliki banyak pembaca baik nasional maupun internasional. Memahami makna teks dalam bahasa asing merupakan suatu usaha yang sulit dilakukan untuk pembaca non-native. Untuk mencapai pemahaman makna teks, deiksis dapat digunakan untuk membantu pembaca non-native. Ada 5 jenis deiksis, yaitu (1) deiksis orang (person) (2) deiksis tempat (3) deiksis waktu (4) deiksis wacana (5) deiksis sosial. Metode deskriptif kualitatif digunakan dalam penelitian ini. Sumber datanya adalah artikel-artikel dalam bisnis yang terdapat di Harian Jakarta Post. Analisis data dilakukan dengan menggunakan teori pragmatik yang dikemukakan oleh teori Levinson. Setelah menganalisis data, para peneliti menemukan bahwa: 1) semua jenis deiksis terdapat pada artikel di Harian Jakarta Post, 2) jenis deiksis yang dominan terdapat pada artikel di Harian Jakarta Post adalah deiksis orang.
\end{abstract}

Kata Kunci: Deiksis, pragmatik, makna, teks

\section{INTRODUCTION}

Herman (2014) said that language is merely human being and non-instinctive way of conversing thoughts, feelings, and wishes through means of a scheme of voluntarily created signs. Therefore, Hutajulu and Herman (2019:29) declared that language is as the instrument of communique that has the crucial element in creating communiqué. Since language has the essential position in communiqué, consequently there is an exact research to talk about language. A language is used to converse amongst community, and it stands for the character and manners of community itself. Creature essentially lives in civilization to converse one to another. Communication symbolizes the essential and basic communal procedure in human living. Communication will be recognized if the aim of language employed is suitable through the circumstances or situation of the narrator and the discourse that is completed. Those aspects are typically conversed in pragmatic.

Yule (1995:3) utters that pragmatics is the study of narrator sense. Pragmatics associated by the redefinitions of the individual tasks of narrator/researchers and receiver/readers in the procedure of improvement. Furthermore, when the narrator utters something, it is significant to the listener respect to construct redefinition what the narrators intended through the expression. Since there are several explanations by the viewers or readers, it desires to be conscious what the narrator wants precisely.

Each information spoken by narrators refers to dissimilar things. In fact, comprehending the sense of the narrator is complicated if the narrator doesn't comprehend the framework of conversation. Deixis is a system of stating to something associated of the narrator framework. 
Levinson (1983:54) defines that fundamentally deixis unease the ways wherein language instruct or grammatical elements of the framework of expression or communication event, and in consequence as well unease customs wherein the understanding of expression depends on the analysis of that framework of expression. Additionally, deixis refers to something in present moment, place, and context of narrator and listener via expression. According to Levinson (1983:65), conventionally dietic term is alienated into five aspects. They are person, place, time, discourse, and social deixis. The five deixis count on the understanding of narrators and communication allies who are in the identical circumstance. Communication can be done through newspaper, radio, television, and so on. Communication can be categorized to be successful if the information whether spoken or written if the addressee/listener/reader can get the context of the information. Readers are always having problem to get the sense of the information through text because of the text is written in foreign language, English. Jakarta Post is one of the media in Indonesia provides the information through text in English. English is as a foreign language in Indonesia. As non-native readers, comprehending the sense of the text is not easy. Deixis is used to interpreter referring of expressions depends on the background expression. It means that it will be better if the reader comprehend deixis to determine the sense in a text.

Wahyudi (2014) in his research entitled Pragmatics Study on Deixis in the Jakarta Post Editorial explained about problems from the readers too. He discussed about the lack of ability from the readers of newspaper to classify the referents of $I$, you, us, this, afternoon or tomorrow. They comprehend how the first three and the last two are associated to one another since the referent of ' $I$ ' is part of the referent of 'us' and the time sequence of "this afternoon and tomorrow" the meaning depends to several extent on the context wherein it arises but deitics can only be construed through their context.

From the importance of deixis and problems stated with the reference of the previous research above, the researchers decided to conduct a research a research in articles of the Jakarta Post. In the articles, there are types of deixis that used by author to help the reader to understand the text. Deixis is used to interpreter referring of expressions depends on the context utterance. It means that it will be better if the addressee recognize deixis to determine the sense in a text.

In this paper, the researchers will make a research of analyzing deixis in the business articles of the Jakarta Post. The researchers focused on five types of deixis based on theory of Levinson to make the readers getting information about who are the speaker and the hearer, where, and when the events take place to make them comprehend the text. For that reason, the researcher makes further analysis of pragmatics especially in deixis. It is hoped that this research will give contribution for the readers of article and also for the teacher and students who study the pragmatics especially in deixis.

\section{RESEARCH METHODOLOGY}

In this paper, this research was carried out in descriptive qualitative research. Sudaryanto (1993:62) defines that descriptive research is a research completed exclusively based on the truth. Hence, Creswell (2011:4) as cited in Pasaribu, Herman and Hutahaean (2020:15) stated that qualitative research is a research for exploring and comprehend the meaning individuals or groups a scribe to social or human problem. It means that this research concerned with the research data that does not contain the statistics, but in the shape of words and phrases. Referring to the previous argumentation, it can be incidental that descriptive qualitative research is a research completed through truth to attain the research goal to obtain the data in the shape of words and phrases.

\section{Data Source}

The source of data in this research was the article in the Jakarta post selected especially the business article. There are five business articles to be chosen in order to be used as the data in this research. This business articles were chosen because of the business articles contain some deitic words and their contexts the type and references of deixis.

\section{Technique of Data Collection}

The researchers used documentation method to collect the data. the documentation method follows some steps such as:

a) Searching the data

b) Collecting the data

c) Reading the data and,

d) Observing the data

e) Taking the data and presenting them in data display, and

f) Drawing and finding conclusions

Technique of Data Analysis 
After getting the data, the researchers used some steps in analyzing the data as following:

a. Describing the types of deixis (person deixis, time deixis, place deixis, discourse deixis and social deixis ) based on the Levinson's theory

b. Analyzing the business article of the Jakarta Post

c. Finding the deixis used in the business article of the Jakarta Post.

d. Drawing conclusions on the results of analysis.

\section{Triangulation}

The validity of a research can be seen by triangulation. Denzin (1978) in Unaids (2010:14) stated that data triangulation is the apply of a diversity of data sources, as well as time, space and persons, in a research. Hence, Denzin (1978) in Unaids (2010:219) acknowledged four basic kinds of triangulation: (1) data triangulation: the use of multiple data sources in a single study; (2) investigator triangulation: the use of multiple investigator/ researchers to study a particular phenomenon; (3) theory triangulation: the use of multiple perspectives to interpret the results of a study, and (4), methodological triangulation: the use of multiple methods to conduct a study. This research was conducted by using are data triangulation for this research attempted to check the validity of the data (types of deixis) within the source data of the research (articles in the Jakarta Post).

\section{FINDING AND DISCUSSION}

After analyzing the data, the researchers found in his research that all types of deixis found in the business article of the Jakarta Post. The types of deixis used are: person deixis, place deixis, time deixis, discourse deixis, social deixis.

After analyzing the data and results from the previous tables above, the researchers come to the total percentage that can be seen in the following table 1 .

Table 1. The total Percentage of the Types of Deixis in Each Article

\begin{tabular}{|c|c|c|c|c|c|c|c|}
\hline \multirow{2}{*}{$\begin{array}{l}\mathbf{N} \\
\mathbf{O}\end{array}$} & \multirow{2}{*}{$\begin{array}{c}\text { TITLE } \\
\text { OF } \\
\text { ARTICL } \\
\text { E }\end{array}$} & \multicolumn{5}{|c|}{ TYPES OF DEIXIS } & \multirow{2}{*}{$\begin{array}{c}\text { TOT } \\
\text { AL }\end{array}$} \\
\hline & & $\begin{array}{l}\text { P. } \\
\text { D }\end{array}$ & $\begin{array}{l}\text { PL } \\
\text {.D }\end{array}$ & T.D & $\begin{array}{l}\text { D. } \\
\text { D }\end{array}$ & $\begin{array}{l}\text { S. } \\
\text { D }\end{array}$ & \\
\hline 1. & $\begin{array}{l}\text { Indonesia } \\
\text { inches } \\
\text { closer to } \\
\text { middle }\end{array}$ & 5 & 2 & 2 & 2 & 0 & 11 \\
\hline
\end{tabular}

\begin{tabular}{|c|l|l|l|l|l|l|l|}
\hline \multirow{2}{*}{$\begin{array}{c}\text { N } \\
\text { O }\end{array}$} & \multicolumn{1}{|c|}{$\begin{array}{c}\text { TITLE } \\
\text { ORTICL } \\
\text { E }\end{array}$} & \multicolumn{3}{|c|}{ TYPES OF DEIXIS } & \multirow{2}{*}{$\begin{array}{c}\text { TOT } \\
\text { AL }\end{array}$} \\
\cline { 2 - 6 } & $\begin{array}{l}\text { P. } \\
\text { D }\end{array}$ & $\begin{array}{c}\text { PL } \\
\text {.D }\end{array}$ & T.D & $\begin{array}{c}\text { D. } \\
\text { D }\end{array}$ & $\begin{array}{c}\text { S. } \\
\text { D }\end{array}$ & \\
\hline $\begin{array}{l}\text { income } \\
\text { trap: } \\
\text { experts }\end{array}$ & & & & & & \\
\hline 2. & $\begin{array}{l}\text { Major } \\
\text { overhaul } \\
\text { to ease } \\
\text { business }\end{array}$ & 6 & 1 & 2 & 3 & 2 & 14 \\
\hline 3. & $\begin{array}{l}\text { Jokowi } \\
\text { urges } \\
\text { developm } \\
\text { ent of e- } \\
\text { commerce }\end{array}$ & 10 & 1 & 0 & 1 & 1 & 13 \\
\hline 4. & $\begin{array}{l}\text { Palm-oil } \\
\text { levy could } \\
\text { be } \\
\text { extended } \\
\text { to rubber, } \\
\text { coffee }\end{array}$ & 6 & 1 & 2 & 0 & 0 & 9 \\
\hline 5. & $\begin{array}{l}\text { Jokowi } \\
\text { tells } \\
\text { Germans } \\
\text { Indonesia } \\
\text { means } \\
\text { business }\end{array}$ & 6 & 0 & 1 & 0 & 1 & 8 \\
\hline TOTAL & 33 & 5 & 7 & 6 & 4 & 55 \\
\hline $\begin{array}{l}\text { PERCEN } \\
\text { TAGE }\end{array}$ & 60 & 10 & 12, & 11 & 7,2 & 100 \\
$\%$ & $7 \%$ & $\%$ & $\%$ \\
\hline
\end{tabular}

The dominant type of deixis found in the business article of the Jakarta Post

After analyzing the data above, the researchers found that the dominant type of deixis used in the business article of the Jakarta Post is person deixis. There are 33 of person deixis $(60 \%)$ found from the whole article of the Jakarta Post. It can be seen from the table of result analysis in each article in the finding of the research. The next dominant in the business article of the Jakarta Post is time deixis. There are 7 time deixis $(12,7 \%)$ found from the whole article of the Jakarta Post.

\section{Discussion}

Based on the finding above, the researchers inferred that there was a similarity with the findings from a previous research done by Wahyudi (2014) entitled Pragmatics Study on Deixis in the Jakarta Post Editorial. Theories used were the same by Levinson about Personal diexis, temporal deixis, spatial deixis, discourse dexis, and social deixis. The difference was lied on the combination theories from Levinson and Halliday and Hasan in Wahyudi's research. Halliday and Hasan theory (1975) cover referential devices that can create cohesion: anaphoric, cataphoric, and exophoric and three types of reference personal, demonstrative and comparative. Meanwhile, this research was only 
done by using theory of Levinson. In short, the use of deixis can help listener/audience/readers in understanding the content or message from the text given.

Hence, the researchers also would like to present the types of deixis found in every article of the Jakarta Post. Below tables are the detail results after data analysis.

1. Type of deixis found in the business article of the Jakarta Post

Data 1 Type of deixis found in business article of the Jakarta Post entitled Indonesia inches closer to middle income trap: experts

After analyzing the article, the researchers got the result below in table 2

Table 2. Types of Deixis found in article entitled "Indonesia Inches Closer To Middle Income Trap: Experts"

\begin{tabular}{|l|l|l|l|}
\hline No & Type of deixis & Total & Percentage \\
\hline 1. & Person deixis & 5 & $45,4 \%$ \\
\hline 2. & Place deixis & 2 & $18,2 \%$ \\
\hline 3. & Time deixis & 2 & $18,2 \%$ \\
\hline 4. & Discourse deixis & 2 & $18,2 \%$ \\
\hline 5. & Social deixis & 0 & - \\
\hline & \multicolumn{3}{|l}{} \\
\hline
\end{tabular}

Data 2 Type of deixis found in business article Jakarta Post entitled Indonesia inches closer to middle income trap: experts

After analyzing the article, the researchers got the result below in table 3

Table 3. Types of Deixis found in article entitled "Indonesia Inches Closer To Middle Income Trap: Experts"

\begin{tabular}{|l|l|l|l|}
\hline No & Type of deixis & Total & Percentage \\
\hline 1. & Person deixis & 6 & $42,9 \%$ \\
\hline 2. & Place deixis & 1 & $7,1 \%$ \\
\hline 3. & Time deixis & 2 & $14,3 \%$ \\
\hline 4. & Discourse deixis & 3 & $21,4 \%$ \\
\hline 5. & Social deixis & 2 & $14,3 \%$ \\
\hline & \multicolumn{3}{|l}{} \\
\hline
\end{tabular}

Data 3 Type of deixis found in business article Jakarta Post entitled Jokowi urges development of e-commerce

After analyzing the article, the researchers got the result below in table 4

Table 4. Types of Deixis in article entitled "Jokowi Urges Development of E-Commerce"

\begin{tabular}{|l|l|l|l|}
\hline No & Type of deixis & Total & Percentage \\
\hline 1. & Person deixis & 10 & $76,9 \%$ \\
\hline 2. & Place deixis & 1 & $7,7 \%$ \\
\hline 3. & Time deixis & 0 & - \\
\hline 4. & Discourse deixis & 1 & $7,7 \%$ \\
\hline 5. & Social deixis & 1 & $7,7 \%$ \\
\hline & \multicolumn{2}{|l}{} & $100 \%$ \\
\hline
\end{tabular}

Data 4 Type of deixis found in business article Jakarta Post entitled Palm-oil levy could be extended to rubber, coffee

After analyzing the article, the researchers got the result below in table 5

Table 5. Types of Deixis found in article entitled "Palm-oil Levy Could Be Extended To Rubber, Coffee"

\begin{tabular}{|l|l|l|l|}
\hline No & Type of deixis & Total & Percentage \\
\hline 1. & Person deixis & 6 & $66,7 \%$ \\
\hline 2. & Place deixis & 1 & $11,1 \%$ \\
\hline 3. & Time deixis & 2 & $22,2 \%$ \\
\hline 4. & Discourse deixis & 0 & - \\
\hline 5. & Social deixis & 0 & - \\
\hline & \multicolumn{2}{|l|}{} & $100 \%$ \\
\hline
\end{tabular}

Data 5 Type of deixis found in business article Jakarta Post entitled Jokowi tells Germans Indonesia means business

After analyzing the data, the researchers got the result below in table 6

Table 6. Types of Deixis found in article entitled Jokowi Tells Germans Indonesia Means Business

\begin{tabular}{|l|l|l|l|}
\hline No & Type of deixis & Total & Percentage \\
\hline 1. & Person deixis & 6 & $75 \%$ \\
\hline 2. & Place deixis & 0 & - \\
\hline 3. & Time deixis & 1 & $12,5 \%$ \\
\hline 4. & Discourse deixis & 0 & - \\
\hline 5. & Social deixis & 1 & $12,5 \%$ \\
\hline & \multicolumn{3}{|l}{} \\
\hline
\end{tabular}

\section{CONCLUSION}

After describing an overview about the types of deixis and analyzing them in the business article of the Jakarta Post, some conclusions are drawn as the following:

1. Based on the each article, all types of deixis are found in the business article of the Jakarta Post, they are: person deixis, place deixis, time deixis, discourse deixis, social deixis. 
2. The dominant types of deixis which is used in the business article of Jakarta Post is person deixis

This paper has shown the analysis of deixis in the business article of the Jakarta Post. More research is also needed to be conducted to make further analysis in other kinds of text in order to get a better understanding of deixis of pragmatics because the researchers feel that research through article is not enough to suffice human's need in further studying of deixis.

\section{ACKNOWLEDGEMENT}

The researchers would like to say thanks to LPPM of Universitas HKBP Nommensen for the support by a research grant according to research contract in 2019/2020.

\section{REFERENCES}

Cohen, L. (2007). Research methods in education. London: Routledge

Herman. (2015). Illocutionary acts analysis of Chinese in Pematangsiantar. International Journal of Humanities and Social Science Invention. ANED. 29.7722/0401202041048

Hutajulu, F. S. L and Herman (2019). Analysis of illocutionary act in the movie "You Are My Home" English Subtitle. Journal of English Educational Study. Volume 2 Issues 1 May 2019 Page 29-36. E-ISSN: 2655-0776

Grundy, P. (2000). Doing pagmatic. New York: Oxford University Press.

Levinson, S. C. (1983). Pragmatics. London: Cambridge University Press.
Lyons, J. (1983). Introductions to theoretical linguistics. London: Cambridge

University Press.

Pasaribu, B., Herman, and Hutahaean, D. T. 2020. Students' Difficulties in Translating Narrative Text From English Into Indonesia at Grade VIII of SMP Negeri 9 Pematangsiantar.Acitya: Journal of Teaching \& Education, 2(1), 13. Accessed from http://journals.umkt.ac.id/index.php/acitya/ article/view/1311

Mayer, C. F. (2009). Introducing English linguistics. Oxford, New York: Oxford University Press.

Mey, J. L. (1993). Pragmatics: An introduction. Oxford UK and Cambridge University USA: Blackwell.

Peccei, J.S. (1999). Pragmatics. London: Taylor and Francis Limited

Sitorus, E. and Herman. (2019). A deixis analysis of song lyrics in Calum Scott "You Are the Reason". International Journal of Science and Qualitative Analysis, 5(1), 24-28. DOI: 10.11648/j.ijsqa.20190501.14

Unaids. (2010). An Introduction to triangulation. UNAIDS Evaluation and Monitoring Fundamental.

Wahyudi. (2014). Pragmatics study on deixis in the

Jakarta Post Editorial. Jurnal Penelitian Humaniora, Vol. 15, No. 2, Agustus 2014: PP. 111-120

Yule, G. (1996). Pragmatics. Oxford, New York: Oxford University Press. 